\title{
Bilateral popliteal artery entrapment syndrome: case report
}

\author{
Síndrome do aprisionamento da artéria poplítea \\ bilateral: relato de caso
}

\begin{abstract}
Fabricio Mascarenhas de Oliveira, ${ }^{1}$ Aline Cristine Barbosa Santos, ${ }^{1}$ Alexandre Mitoshi Takito, ${ }^{2}$ Edgard Bolanho, ${ }^{2}$ Regina de Faria Bittencourt da Costa, ${ }^{3}$ Nelson Fernandes Jr. ${ }^{4}$
\end{abstract}

\begin{abstract}
Popliteal artery entrapment syndrome occurs due to an extrinsic compression of the popliteal vessels that results in vascular damage. It is one of the most frequent causes of intermittent claudication in young patients. The authors describe a case of bilateral syndrome by anomalous position of the gastrocnemius muscle, with abnormal slip of its medial head (Rich's type III). During the operation the occluded right side was reconstructed by autologous saphenous vein bypass from femoral superficial to peroneal artery and on the left side the slip muscle was transected by posterior approach. Popliteal artery entrapment syndrome should be treated by surgery despite the degree of symptoms. Surgical treatment technique has released the vessel by extracting the muscle that caused entrapment, and reconstructing the narrow lumen bypass grafting.
\end{abstract}

Keywords: Popliteal artery, surgery, popliteal artery entrapment syndrome.

\section{Introduction}

Popliteal artery entrapment syndrome is an unusual disease that typically affects young athletic males, causing symptoms of claudication and chronic leg ischemia. ${ }^{1-3}$ The prevalence is in a $0.16-3.5 \%$ range in the general population. ${ }^{4}$ In younger patients (under 30 years) it appears as an intermittent claudication, in which this etiology occurs in around $40 \%{ }^{5,6} \mathrm{It}$ is caused by an

\begin{abstract}
Resumo
A síndrome do aprisionamento da artéria poplítea ocorre em função de compressão extrínseca dos vasos poplíteos, que resulta em lesão vascular. Trata-se de uma das causas mais freqüentes de claudicação intermitente em pacientes jovens. Os autores descrevem um caso de síndrome bilateral devida à posição anômala do músculo gastrocnêmio, com deslizamento de sua cabeça média (tipo III da classificação de Rich). Durante a cirurgia, o lado direito ocluído foi reconstruído por derivação da veia safena autóloga da artéria superficial femoral para a artéria peroneal e, do lado esquerdo, o músculo que sofreu o deslizamento foi secionado através de via posterior. A síndrome do aprisionamento da artéria poplítea deve ser tratada por cirurgia, independente do grau dos sintomas. A técnica de tratamento cirúrgico liberou o vaso, extraindo o músculo que causava o aprisionamento e reconstruindo o lúmen estreito por derivação.
\end{abstract}

Palavras-chave: Artéria poplítea, cirurgia, síndrome do aprisionamento da artéria poplítea.

anomalous relationship between the muscle and the artery in the popliteal fossa resulting in extrinsic arterial compression. Repetitive trauma in the popliteal artery can cause arterial damage and lead to aneurysm, thromboembolism, and arterial thrombosis. The symptomatic history leads to an early diagnosis and treatment. The following case is an example that describes a bilateral popliteal artery entrapment.

1. Residente ( $2^{\circ}$ ano), Serviço de Cirurgia Vascular, Hospital Heliópolis, São Paulo, SP, Brazil.

2. Médico assistente, Serviço de Cirurgia Vascular, Hospital Heliópolis, São Paulo, SP, Brazil.

3. Membro titular, SBACV-SP. Doutora em Medicina, Universidade Federal de São Paulo - Escola Paulista de Medicina (UNIFESP-EPM), São Paulo, SP, Brazil. Diretora de Clínicas Cirúrgicas e médica assistente, Serviço de Cirurgia Vascular, Hospital Heliópolis, São Paulo, SP, Brazil.

4. Chefe, Serviço de Cirurgia Vascular, Hospital Heliópolis, São Paulo, SP, Brazil. Especialista em Angiologia e Cirurgia Vascular, Conselho Federal de Medicina (CFM). Especialista em Angioradiologia Intervencionista e Cirurgia Endovascular, SoBRICE-CBR.

Article presented at $37^{\circ}$ Congresso Brasileiro de Cirurgia Vascular.

No conflicts of interest declared concerning the publication of this case report.

Manuscript received Nov 21 2007, accepted for publication Mar 112008.

J Vasc Bras. 2008(2):159-162.

Copyright $\odot 2008$ by Sociedade Brasileira de Angiologia e de Cirurgia Vascular 


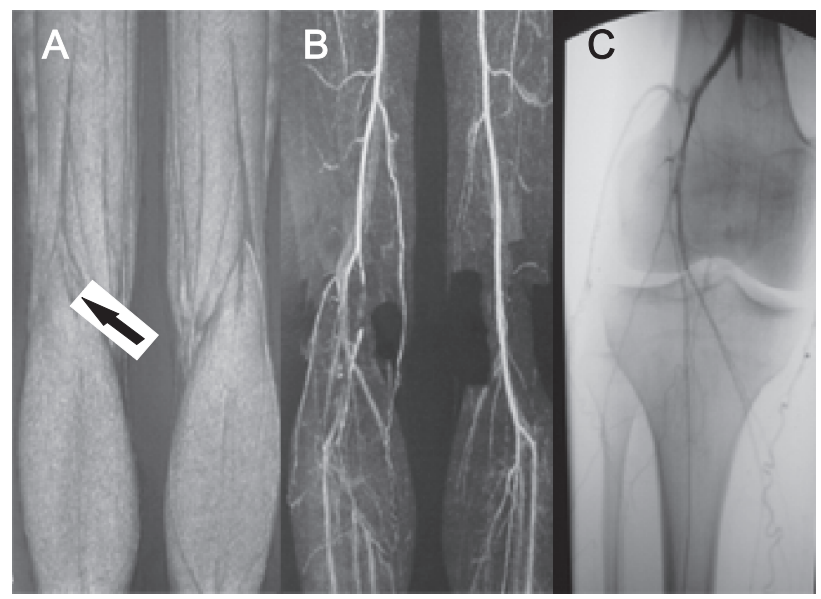

Figure 1 - A) Magnetic resonance showing Rich's type 3 entrapment (arrow); B) resonance with right popliteal artery occlusion; C) arteriogram confirming right popliteal artery occlusion

\section{Case report}

A 20-year-old white man was admitted to our medical service center with intermittent claudication in his right leg after walking a 200 -meter distance. He had been having this symptom for 5 years and had been taking cilostazol $100 \mathrm{mg}$ a day for 6 months. The patient had never performed any intensive physical exercise. There was no family history of peripheral vascular or embolic disease, no history of trauma either. The patient reported he never smoked. The physical examination was normal, except for the fact of absent right tibial pulses and decreased tibial pulses palpable in his left leg in the plantar flexion. The ankle-brachial index (ABI) was 0.6 at the right and 1.0 at the left limb. With stress maneuver the ABI was equal to 0.6 at the left, suggestive of popliteal entrapment.

Duplex scan showed occlusion of the right popliteal artery. Magnetic resonance image of the lower limbs revealed bilateral entrapment of the popliteal artery by an accessory muscle head of the medium part of the gastrocnemius muscle (Figure 1A and B). Arteriography confirmed occlusion of the right popliteal artery (Figure 1C) with collateral circulation and a functional angiogram in active flexion of the left limb revealed compression of the popliteal artery (Figure 2A, B and C).
Posterior surgical approach of the left limb showed anomalous position of the gastrocnemius muscle, with abnormal slip of its medial head. The slip muscle was transected and there was no more evidence of compression of a healthy popliteal artery (Figure 2D). Afterward, the patient was changed to dorsal position and a medial approach to the right popliteal artery was performed. A thrombus in the popliteal artery (stage 3) with no distal reflux was observed. Reconstruction of the occluded segment with long autologous saphenous vein bypass from superficial femoral to peroneal artery was performed (Figure 2E).

A 30-day postoperative arteriogram showed absence of the left popliteal artery compression as a result of dynamic maneuvers (Figure 3A) and right vein bypass occlusion (Figure 3B). The left ABI using the same dynamic maneuvers was 1.0 and remained 0.6 at the right.

The patient is under vasodilator (cilostazol 200 $\mathrm{mg} / \mathrm{day}$ ) and is attending our follow-up ambulatory care. However, intermittent claudication after walking 200 meters still continues.

\section{Discussion}

Young patients suffering from intermittent claudication and with no risk factors for arterial diseases must be carefully observed. The main problem in treating popliteal entrapment is the appropriate diagnosis. ${ }^{1-3,6}$ Different diagnoses include arteritis, neurogenic claudication, muscular disease, tumors in popliteal adventitial cavity, cystic disease of the popliteal artery and injuries to the popliteal artery affected by traumatic causes. ${ }^{4,7-9}$

The syndrome can be divided into two categories: anatomic and functional entrapment. ${ }^{8}$ In spite of that, the most acceptable is Rich's classification into five types, based on the embryologic aspect. Recent reports $3,8,10$ have defined functional entrapment as intermittent claudication with popliteal artery compression at stress maneuvers, although the patient does not present any apparent anatomic abnormality. Our patient had a type III entrapment (the most common type, with a $35 \%$ prevalence rate), in which the accessory slip of the medial head of the gastrocnemius muscle arose from the medial femoral condyles. ${ }^{1,6,11}$ 


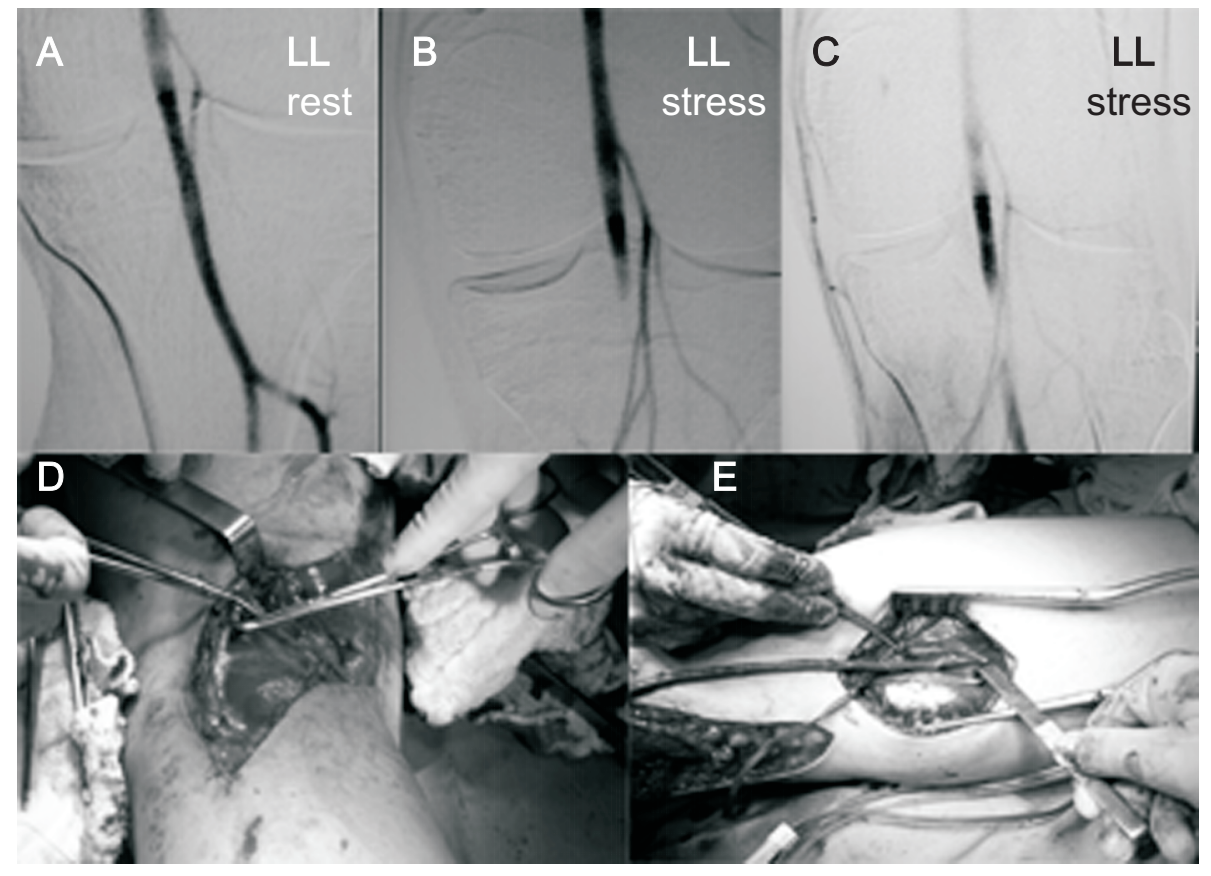

$\mathrm{LL}=$ left limb.

Figure 2 - A) Arteriogram showing normal popliteal artery at rest; B, C) occlusion of the left popliteal artery at stress maneuvers; D) posterior approach to entrapment popliteal; E) right limb with saphenous vein bypass

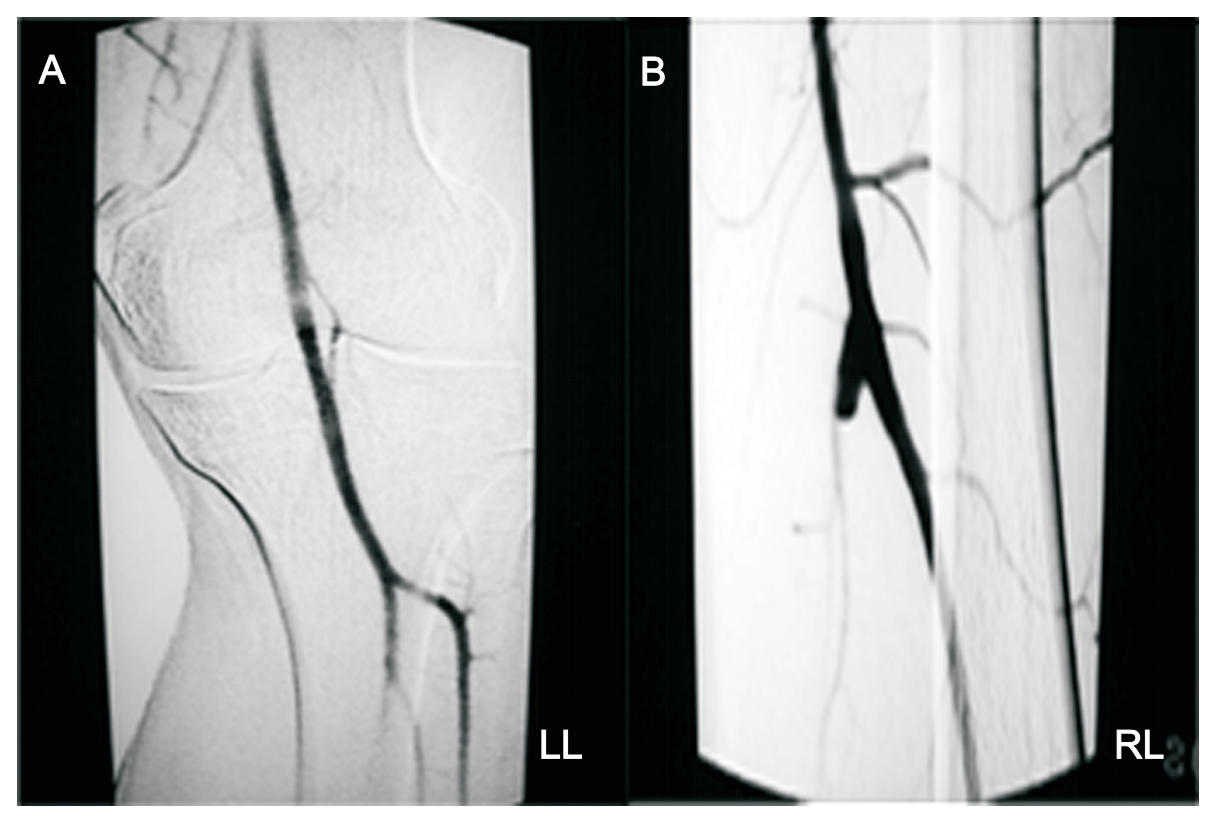

$\mathrm{LL}=$ left limb; $\mathrm{RL}=$ right limb.

Figure 3 - A) Arteriogram after surgery demonstrating normal left popliteal artery at stress maneuvers; B) occlusion of right saphenous vein bypass 
Duplex scan could be used to identify popliteal artery compression through decreases in blood flow at dorsiflexion maneuver. However, the patient's symptoms must always be considered, because popliteal occlusion at stress maneuver can be found in more than $50 \%$ of healthy people. ${ }^{4,8-10}$

Computed tomography scan shows artery occlusion, but it is not always able to delineate anomalous insertion of muscle. Magnetic resonance angiography provides detailed information regarding the relationship between vascular and musculotendinous structures within and around the popliteal fossa. ${ }^{2,12}$ Contrast arteriography is very useful to plan bypass surgery.

We performed a resection of muscle slip in the left limb with posterior approach because it would better define an anomalous anatomy. ${ }^{2,3} \mathrm{~A}$ bypass had to be performed in the right limb to avoid ischemic pain, since the patient had been taking cilostazol $100 \mathrm{mg} /$ day for 6 months with no success. We assumed that the bypass occluded because there was thrombus in the popliteal artery with poor artery reflux (stage 3 disease - replacement of the intima to collagen scar tissue).

Definitely, we consider that treatment for popliteal artery entrapment syndrome is surgical intervention. ${ }^{1,4-7,10,13,14}$ Because of the progressive nature of this disease, even in the case of symptomatic claudication in limbs, a surgical correction should be performed to avoid an irreversible damage. Decompression with musculotendinous transection is advisable in all cases of anatomical popliteal entrapment, and if significant degeneration or occlusion of the popliteal artery occurs, arterial reconstruction could be performed. ${ }^{3}$

Endovascular treatment is not effective without removing the underlying reason of vessel entrapment, in which case the risk of reocclusion is high. Treatment of the popliteal occlusion by angioplasty can be an appropriate approach after removing the obstacle causing the entrapment.

\section{References}

1. Hamming JJ. Intermittent claudication at an early age, due to an anomalous course of the popliteal artery. Angiology. 1959;10:369-71.

2. Turnipseed WD. Clinical review of patients treated for atypical claudication: a 28-year experience. J Vasc Surg. 2004;40:79-85.

3. Turnipseed WD. Popliteal entrapment syndrome. J Vasc Surg. 2002;35:910-5.

4. Castiglia V. Síndrome do aprisionamento da artéria poplítea. Revisão de literatura. In: Maffei FHA, Lastória S, Yoshida WB, Rollo HA, editores. Doenças vasculares periféricas. 3a ed. Rio de Janeiro: Medsi; 2002. p. 1305-16.

5. Erdoes LS, Devine JJ, Bernhard VM, Baker MR, Berman SS, Hunter GC. Popliteal vascular compression in a normal population. J Vasc Surg. 1994;20:978-86.

6. Hamming JJ, Vink M. Obstruction of the popliteal artery at an early age. J Cardiovasc Surg (Torino). 1965;6:516-24.

7. Akkersdijk WL, de Ruyter JM, Lapham R, Mali W, Eikelboom BC. Colour duplex ultrasonographic imaging and provocation of popliteal artery compression. Eur J Vasc Endovasc Surg. 1995;10:342-5.

8. Rignault DP, Pailler JL, Lunel F. The "functional" popliteal entrapment syndrome. Int Angiol. 1985;4:341-3.

9. Turnipseed WD, Pozniak M. Popliteal entrapment as a result of neurovascular compression by the soleus and plantaris muscles. J Vasc Surg. 1992;15:285-93.

10. Levien LJ, Veller MG. Popliteal artery entrapment syndrome: more common than previous recognized. J Vasc Surg. 1999;30:587-98.

11. Rich NM, Collins GJ Jr., McDonald PT, Kozloff L, Clagett GP, Collins JT. Popliteal vascular entrapment. Its increasing interest. Arch Surg. 1979;114:1377-84.

12. Rich NM, Hughes CW. Popliteal artery and vein entrapment. Am J Surg. 1967;113:696-8.

13. Almeida MJ, Yoshida WB, Melo NR. Síndrome do aprisionamento da artéria poplítea. J Vasc Bras. 2003;2:211-19.

14. Araújo JD, Araújo Filho JD, Ciorlin E, Oliveira AP, Manrique GES, Pereira AD. Aprisionamento de vasos poplíteos: diagnóstico e tratamento e o conceito do aprisionamento funcional. J Vasc Bras. 2002;1:22-31.

Correspondence:

Fabricio Mascarenhas de Oliveira

Rua Guararapes, 228/44

CEP 04561-000 - São Paulo, SP - Brazil

E-mail: fabriciomasc@uol.com.br 